\title{
Bullying in the Post Truth Era (Analysis of Implementation of Realistic Counseling in Early Adolescents in Kuningan District)
}

\author{
$1^{\text {st }}$ Ika Candra Destiyanti \\ Universitas Islam Al Ihya Kuningan \\ Kunigan, Jawa Barat \\ ikacandradestiyanti@gmail.com
}

\begin{abstract}
Bullying among students in school often occurs in early adolescence which impacts on someone who has been bullied tends to bully people who are weaker than themselves. Starting from the framework of thought that the act of bullying is a desire to hurt that is shown in the action and cause someone to suffer that is done repeatedly. Using qualitative methods of phenomenology. Implementation of counseling reality done at school can reduce traumatic behavior in children, especially victims of bullying. From the results of the discussion it was found that the act of bullying in the post truth era was due to the influence of social media, parenting and relationships so that the behavior was difficult to overcome in a short time. Feelings are not valued and feel hurt significantly will increase traumatic to bully victims. Therefore the impact of problems faced by children and adolescents must be addressed immediately with appropriate interventions. The efforts of parents and schools to overcome bullying through realistis crisis counseling in order to foster a generation that is stable, optimistic, unemotional and avoiding traumatic.
\end{abstract}

Keywords—bullying, truth pist area, realistic counseling, early adolescents

\section{INTRODUCTION}

Bullying is a phenomenon that occurs among school children as an identity of one's position in the social environment. Bullying is also the centre of attention of teachers and parents as an act that often occurs in juvenile delinquency cases. Bullying in the past and present has several differences. Past bullying has occurred in children from underprivileged families, has learning difficulties and belongs to the group of inclusive children. Bullying nowadays occurs in groups of smart children, have above average abilities and have good relationships. The prevalence of victims of bullying is between 8 and $50 \%$ in Asian, American and European countries. Surveys in various parts of the world stated that bullying most often occurs at the age of 7 years (grade II elementary school), and then decreases until the age of 15 years. Another study states the highest prevalence of bullying at the age of 7 years and 10-12 years. Boys are more often involved in bullying than girls ${ }^{1}$.
To solve the bullying case, the school must know who is the perpetrator and victim of bullying ${ }^{2}$. Social support and eating family meals together promotes resilience by buffering adolescents against the consequences at Resilience to bullying and cyberbullying ${ }^{3}$. Post Truth era which was popularized by Ralph Keyes in his book published in 2004, where the term is increasingly popular in 2016. Even the Oxford Dictionaries Team parallels the phrase post-truth politics that can be interpreted by people easily take any data and make their own conclusions and interpret themselves according to their wishes. This is what triggers bullying difficult to control and triggers bullying victims to become perpetrators of bullying in the future. ${ }^{4}$

According to preliminary data in the field using indepth observation of 100 children of witnesses and victims of Bullying actions, it is clear that those who were witnesses or victims of Bullying have a family background that has a history of broken home ${ }^{5}$. Reseach by Zulfiyaturrizqiyah ${ }^{6}$ which results in the finding that each level of class has a chance of bullying, but the biggest percentage of bullying occurs in grade 7 and grade 8 . Perpetrators are not only among ordinary children but the perpetrators are also among the popular children at school. Bullying is also not only done individually but also done in groups. The cause of the perpetrators of bullying was a problem in the past with victims and the perpetrators also used the popularity of the school to get support from friends and teachers. Lack of attention from the family is also a factor causing children to behave in bullying.

Who have different characteristics or ethnicity from the majority of children in their class. Bullying has an impact on reducing the academic achievement of victims at school, the victim's learning patterns, the victim's social interaction with the people around him and even the victim's daily behavior which can lead to deviations from the victim's behavior to avoid bullying.

In contrast to previous studies where people who have experienced bullying will bully others. This research has an update where the suggestions from previous researchers about researching witnesses or viewers of 
bullying victims who commit acts of bullying against their classmates so that the target of the study is how children who witnessed acts of bullying have the same tendency to do bullying as well as victims of bullying who tend to act immorally. Research from Boston Children's Hospital reveals that the effects of bullying can last longer, even years, on the mental and physical victims of bullying. Research has revealed that bullying can cause a bad impact on children's health. The act of bullying has also been linked to mental and physical health which continues to decline. Bullying children will be more prone to depression and low self-confidence. In addition, the study also found that the brainpower of children affected by bullying will decrease. This certainly has a major impact on children's learning achievement in school. $^{7}$

Preliminary research shows that bullying cases in schools occur because of the lack of supervision during breaks, regulations regarding bullying cases are not consistently enforce ${ }^{8} \mathrm{~d}$ and different understandings or perceptions between teachers and students in dealing with bullying habits ${ }^{9} .{ }^{6}$ Efforts to prevent bullying from the school to avoid the many psychiatric effects, ranging from emotional, physical, academic, self-confidence, cowboy behavior, psychotic, even to suicide, so that cases of violence among adolescents must be handled seriously involving the school, parents and community.

As a child who grows up in a good and religious environment will grow into a generation that is stable, optimistic and not emotional. The role of parents and family will automatically shape the child's personality and mentality to be better and the surrounding environment will also influence it. If the child gets enough protection and attention from those closest to him, the child will be able to face external threats optimistically. However, when there is a deviation in which the role of the school has the biggest role in bullying, it is necessary to find a solution to overcome it so that the bullying process in the post truth era this does not become a land for bullying. For this reason the purpose of conducting research on Bullying Actions in the post-trut era (analysis of implementation of realistic counseling in early adolescents in Kuningan district)

\section{METHOD}

The location of research in the Kuningan district junior high school with research subjects were students in grades 7, 8 and 9. This study used a qualitative phenomenological study. While the Data Collection Technique is through interviews with informants involved in research, in-depth observation and documentation techniques.

Regarding the number of informants taken consisted of:

- Parents Perpetrators and victims of bullying

- Teacher Guidance and Counseling;

- All Homeroom Class Actors and victims of Bullying

While the data analysis technique in this study uses qualitative data analysis, so in the analysis of data while in the field the researcher uses the Spradley model.

\section{RESULT AND DISCUSION}

\section{A. Teacher's efforts to overcome Bullying in the post} truth era

The results of observations in the field explain that almost 70 percent of juvenile delinquency cases occur in bullying problems. The process of bullying is quite diverse, especially in the early adolescent environment where technology has a major influence on adolescent association. From the recapitulation of cases collected from the student division causing bullying divided into 3 groups namely: Social Media, Relationships and disputes. Social Media has the biggest influence on the causes of bullying among early teens.

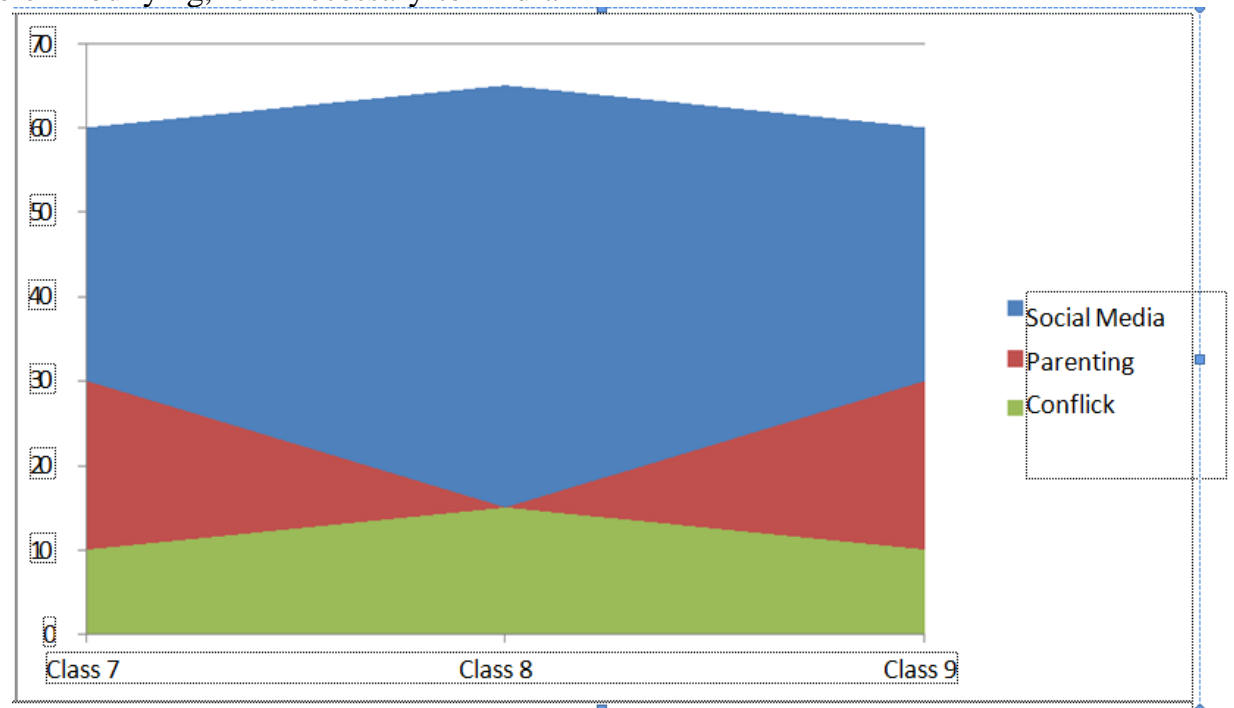

Figure 1. The Prevalence of the Influence of Bullying in Schools 
Phenomenon of Bullying due to the influence of social media has become the spotlight of the school to limit the use of gadgets in the school environment where these preventive measures become the basis of school efforts to tackle bullying more broadly. Furthermore, the school's action in dealing with bullying is to hold realistic counseling so that the counselee in this case the perpetrators and victims of bullying can face the postincident situation. What continues is how the perpetrators and victims can have the same normal feelings as before the incident so they can socialize and re-establish friendships. The stages are

- Engage in role playing with clients

- Using humor

- Facilitate the client and reject any reason from the client

- Help clients formulate a specific plan of action

- Acting as a teacher / model

- Set boundaries - set up therapeutic situations

- Use appropriate verbal shock or sarcasm therapy to confront the client with his unrealistic behaviour

\section{B. Parents' efforts to overcome bullying in the post truth era}

Learn to pronounce Environmental influences are very dominant in influencing early adolescent behavior. But in this post truth era there is a tendency for early adolescents to prefer socializing through social media rather than face to face. The reason is they can look for friendship more broadly than socializing in society, parents can control their children at home and the cost of being popular among friends is far less than meeting face-to-face in the community. However, the impact of association on social media is even higher compared to social interaction in the real world. Quoted from the Liputan 6. Com the influence of social media actually raises psychological disorders in the form of anti-social (Avoiding social contact in the community), Anorexia and bulimia nervosa (desire to have an ideal form by avoiding eating), Megalomia (feeling very popular), Nomophobia (excessive anxiety lost gadgets) and gaming disorder (excessive game play).

Reviewing the research conducted by Ikhsani, L. N. (2015) with the title Phenomenology Study: Psychological Dynamics of Youth Bullying Victims in Teenagers Bullying that occurs among adolescents is verbal bullying while victims of bullying actually get psychological influence because they cannot fight bullying. This spurs bullying cannot be controlled only through the efforts of teachers in schools as well. Need a lot of support to avoid bullying among early adolescents, one of which is community and family support ${ }^{7}$

The high level of online communication on social media triggers bullying due to psychological illnesses experienced and to overcome this need the role of parents present in the early stages of adolescent development. Parents' efforts to add family time activities without gadgets trigger early teens to focus more on their real lives. Coaching gross motor skills through sports and hobbies is an attempt by parents to avoid early adolescents surfing through social media.

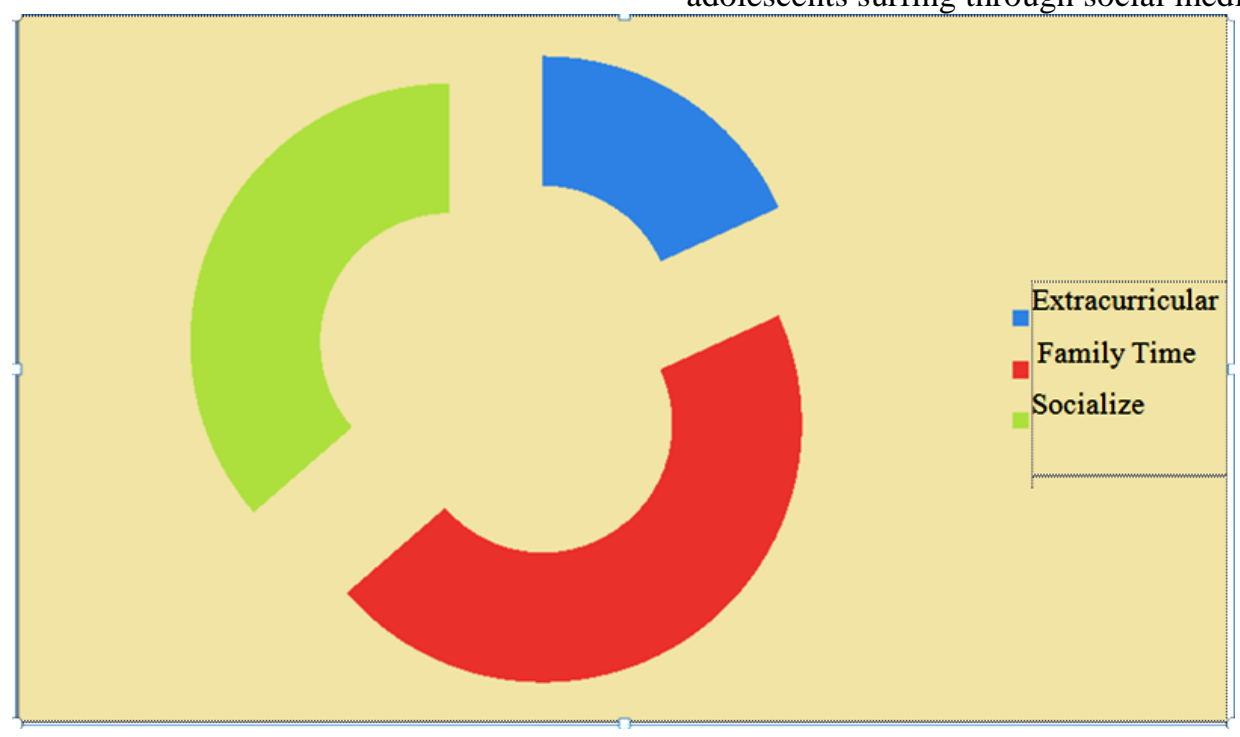

Figure 2. Many attempts by parents to avoid gadgets in early teens

From the interviews and observations of several parents who have cases of bullying from the influence of social media they do prevention by increasing attention to early adolescents at home through lots of communication and doing hobbies together have a higher level than handing over their children to school through extracurricular activities. This is because the desire of their children to get the attention of parents is more necessary than increasing hours at school to socialize with friends. Family Time is the best effort parents can do to prevent bullying of early teens through social media. Through family time active communication occurs 
between parents and children so that the problems that occur can be overcome properly. While community support through organizing has a high percentage under family support through family time, this encourages many parties to be able to contribute to the fight against bullying through social media and in the real world

\section{RESULT}

According to the results of research and discussion, it can be concluded

- School efforts in overcoming bullying in the post truth era can be done through realistic counseling where counselees are given an understanding so that the perpetrators and victims can have the same normal feelings as before the incident and socialize and reestablish friendships.

- Schools can reduce bullying through social media by not allowing students to bring gadgets to school

- Family support has the best prevalence in preventing bullying in the post truth era where the quality of family communication is better in preventing psychological changes experienced by early teens due to social media influences

- Community support to fight against bullying is the best power where early teens have the confidence and comfort to socialize in real life

- Interventions between the school and parents have a positive influence on the efforts of early teens to avoid bullying both online and offline

\section{CONCLUSION}

Through the implementation of realistic counseling in overcoming the post truth bullying, it is suggested

- So that the school can control the students during the break because of the most bullying incidents during recess

- Family and community support plays an important role in providing a positive image of victims and perpetrators of bullying to be able to socialize and socialize in a healthy manner

- There is further research on models of assistance on the part of parents to deal with bullying optimally

\section{REFERENCES}

[1] Neto AAL. Bullying-aggressive behavior among students.

[2] Anna M. Dåderman, Carina Ragnestål-Impola,Workplace bullies, not their victims, score high on the Dark Triad and Extraversion, and low on Agreeableness and HonestyHumility,Heliyon,Volume 5, Issue 10,2019,e02609,ISSN 24058440,https://doi.org/10.1016/j.heliyon.2019.e02609.(http://www. sciencedirect.com/science/article/pii/S2405844019362693)

[3] Antoniadou, N., \& Kokkinos, C. M. (2015). Cyber and school bullying: Same or different phenomena?. Aggression and violent behavior, 25, 363-372.

[4] J Pediatr 2005;81:(S)164-72, Glew G, Rivara F; Feudtner C. Bullying: children hurting children.

[5] Hediatr Rev 2000;21:183-9; Nansel TR, Overpeck M, Pilla RS, Ruan WJ, Morton BS,

[6] Scheidt P. Bullying behaviour among US youth. JAMA 2001;285:2094-100

[7] https://www.indonesiana.id/read/107184/era-post-truthkebenaran-jadi-komoditas
[8] Research While witnesses and victims of bullying at school

[9] Zulfiyaturrizqiyah. 2012. Perilaku Bullying di Kalangan Remaja Awal (Studi Fenomenologi Sekolah Menengah Pertama). Skripsi Program Studi Bimbingan dan Konseling. Fakultas Ilmu Pendidikan. Universitas Negeri Malang.

[10] Fitria, S. N., \& Bakar, D. H. U. A. (2017). PENANGGULANGAN BULLYING DALAM

[11] PERSPEKTIF PENDIDIKAN ISLAM (TELAAH BUKU PENDIDIKAN TANPA KEKERASAN

[12] TIPOLOGI KONDISI, KASUS DAN KONSEP) KARYA: ABD RAHMAN ASSEGAF (Doctoral dissertation, IAIN Surakarta).

[13] Research data on the place and time of bullying

[14] Yusuf Syamsu. (2004). Psikologi Anak dan Remaja. Bandung : PT Remaja Rosdakarya 